\title{
Poetics of Slogans in Yachting ADS
}

\author{
Tomislav Skračić, MA
}

Faculty of Maritime Studies - University of Split, Zrinsko-Frankopanska 38, Split, Croatia, tomislav@pfst. hr

Marko Borak, MSc

MagMaris Agency, Ivana Gundulića 41, 22000 Šibenik, Croatia, marko.borak@magmaris.net

\begin{abstract}
The paper discusses the poetics of yachting slogans - short, simple and memorable advertising statements whose task is to attract the attention of potential consumers and help differentiate the product or the company. The stylistic analysis, including qualitative, descriptive and comparative methods, has been used to identify and examine the poetic elements of slogans in yachting ads: schemes, tropes and additional imagery, with due attention paid to the graphic aspect and the comparative features of slogans in other trades. The paper primarily addresses the students and teachers of English language for Specific Purposes. The results of the analysis are useful for familiarizing with the main principles of figurative language and writing advertising texts, and can provide useful information for literature students, admen, copywriters and all people interested in language of advertising.
\end{abstract}

Keywords: yachting, advertising, slogans, poetics

\section{Introduction}

Life is now, now life begins at 40

Launch into living - so worth it

Capture the dream, a detailed harmony

Feel something special, the sea symphony

Imagine perfection, technologies to trust

\section{Safe. Strong. Fast. Built to last.}

These are not verses written by Charles Baudelaire. And this is not William Butler Yeats either. The six-line stanza, rich in rhymes, alliterations, rhythm and other euphonic devices, inviting the reader to indulge in living and to set off in quest of adventure, harmony and perfection, actually consists of eleven juxtaposed slogans that advertise boats and boating equipment in nautical magazines. The lines may sound like poetry, and perhaps some of them are, but the mission of these seemingly harmless short messages is far more pragmatic and complex. They have been designed and released to attract attention of the targeted population, to create desire and drive to action, the ultimate goal being the purchase of the advertised products and services.

The aim of this study is to identify, define and analyse stylistic features used in advertising slogans of famous yachting brands, with due attention drawn to the figures of speech (expressive language used in a non-standard, non-literal or an 
unusual way) and to their specific motifs and graphics. In addition to the stylistic and qualitative analysis of the slogans' poetic register, descriptive method has been used to provide some theoretical background on poetic devices, occasionally comparing the tools used in yachting industry to the ones identified in other trades.

The corpus includes the slogans supporting advertisements in four nautical magazines published over a one year period, as well as the slogans gathered during a recent one-off web search. ${ }^{1}$ Slogans from other advertising areas, used for illustration and comparison with nautical slogans, have been borrowed from the works cited in the list of references.

The paper primarily addresses the students and teachers of English language for Specific Purposes. The results of the analysis are useful for understanding the main principles of figurative language and writing advertising texts, and can provide useful information for literature students, admen, copywriters and all people interested in language of advertising.

\section{DEFINITION AND MISSION}

According to Geoffrey N. Leech, the slogan is a short phrase used by the company in its advertisements to reinforce the identity of the brand. David P. Rein defines an advertising slogan as a "unique phrase identified with a company or brand". 2 Definitions may vary but all of them point out the same essential aspects: advertising slogans are short, simple, witty and memorable statements whose task is to help differentiate the product or the company from its competitors. In other words, they have to attract potential customers, help them identify and remember the brand and/or the company, and make them buy or use the advertised product or service. Selling power is the crucial principle. Hence, slogans are important marketing tools. Along with other advertising elements (body text, specification, image, logo, video, music, jingle...), they help build a recognisable image for the brand they are representing. ${ }^{3}$

\section{COMMON CHARACTERISTICS}

A slogan usually consists of a few words which sum up the entire message that a company (or city, country, destination...) wants its audience to remember. In advertising business there are two basic types of slogans: brands slogans and business (or corporate) slogans. Brand advertising communicates the specific characteristics, values, and benefits of a particular brand, affecting the way consumers view the brand compared to others: Get TIME, ahead of time (TIME Magazine), Now life begins at 40 (motor yacht Sunseeker Portofino 40). On the other hand, corporate slogans are designed to generate favourable attitude towards a company as a whole. Well-known users of corporate advertising include L'Oréal (Because you're worth it. ), Nike (Just do it). Most boatbuilders use corporate slogans supporting a range of their products: Sea Ray (Launch into living), Bayliner (So worth it), Ferretti (Intelligenza nautica Italiana), etc. However, both types of slogans have similar tasks, structure and poetics. Therefore, for the purpose of this paper, brand slogans and business slogans are jointly referred to as "advertising slogans". 4

In order to perform the above mentioned tasks, advertising slogans have to meet a number of requirements. First of all, a slogan should emphasise a key benefit of a brand, and help differentiate the brand, i. e. make it recognisable on the market. For example, there is a wide range of 40 to 50 -foot power boats with similar design, performance and value-for-money, but a customer may opt for Vanga 44 because its slogan "sounds good" (Your imagination is the limit!) or Brioni 44 because of the flattering message (For Emperors and Princesses) - without realising that they are versions of the same vessel. ${ }^{5}$ Marketing tools are here to drive consumers towards a decision, suggesting that the brand they support is special, unique, better or Different... Like you (Saltus brokerage \& charter). An advertising message is not supposed to be complicated or

\footnotetext{
1 The magazines include More 2010 (Croatia), Nautica (Croatian edition) 2009, Yachting (Croatian edition) 2013, Val navtika 2013 (Slovenia). The web search was performed on January 14, 2016 (search words: "yachting ads").

2 G. N. Leech (1966/1972), English in Advertising: A Linguistic Study of Advertising in Great Britain, London: Longman; D. P. Rein (1982), The Language of Advertising and Merchandising in English. New York: Regent, pp. 49-54; William F. Arens (1994), Contemporary advertising, $5^{\text {th }}$ edition, Irwin, USA, pp. 234-275.

${ }^{3}$ Qunsheng Ke and Weiwei Wang, "The Adjective Frequency in Advertising English Slogans" in: Theory and Practice in Language Studies, Vol. 3, No. 2, Academy Publication, February 2013, pp. 275-284.); See also: Stephen J. Conley, Sloganology: The Anatomy Of Slogans. eBook / www.thesloganshop.com, 2010, pp. 3-6.

4 More about the typology in: Thomas C. O'Guinn; Chris T. Allen; Richard J. Semenik, Advertising and integrated brand promotion, 6th ed., Mason, OH: South-Western, Cengage Learning, 2012, p. 33. Also at: http://www.ediwriter.com (2016-01-23)

5 In 2010 Slovenian company Vanga Yachts redesigned their Vanga 44 lobster and named it Brioni 44.
} 
awkward. The slogan Get everything. Power, space and style. Live Itama. (Itama yachts) is way too descriptive and hard to memorise. In addition, an average boater may find it difficult to understand what "Live Itama" could imply. Likewise, the meaning of the slogan Way of life! (Suzuki 4-stroke outboard motors) is rather foggy and cumbersome: perhaps it would be more appropriate in advertising consumer goods like sportswear or beer. While simplicity is crucial the length may vary: there are very short messages: Think different. (Apple), Legendary strength (Schaefer jib furling systems). On the other hand, David Ogilvy says advertisers "should not be afraid of long slogans". ${ }^{1}$ Huckins Yachts' narrative message IMAGINE OWNING A YACHT THAT INSPIRES YOU TO STARE AT THE SCENERY, NOT THE FUEL GAUGE is lengthy but clear: these power boats are fuel-saving, cost-efficient, reliable, and able to sail long distances, ensuring the boater new experience and pleasure of exploration. ${ }^{2}$

Most importantly, an advertising slogan should be memorable. It has to find its way into consumer's memory and make the consumer feel a desire or need. Memorability may depend on how often and how long the slogan has been used in advertising $^{3}$. It may also depend on how efficiently the slogan is tied to a jingle (e. g. Calgon) and other audio and video material. For example, the slogan Washing machines live longer with Calgon is combined with a catchy jingle that may remain in consumer's memory for years. Yet, the critical factor that makes a slogan memorable is its own "personality", i. e. the language features, the poetics and the message it conveys.

\section{POETICS}

"I do not regard advertising as entertainment or an art form, but as a medium of information," says David Ogilvy. "When I write an advertisement, I don't want you to tell me that you find it creative. I want you to find it so interesting that you buy the product. "4 Indeed, as it was stated above, selling power is crucial, but it should be borne in mind that the power arises from the (creative) use of language. The language used in advertising slogans is essential to the message they want to convey. As the stanza created at the beginning of this paper shows, these poetic devices may include alliteration, assonance, rhyme, metre, rhythm, metaphor, etc. To accomplish their mission effectively, advertising messages make use of figures of speech and other techniques similar to those used in poetry.

Poetic devices or figures of speech can be categorised in various ways. They are often analysed at four levels: phonological, lexical, syntactic and semantic level. They can also be categorised into sound figures, tropes, figures of construction and figures of thought. ${ }^{5}$ For the sake of simplicity, this paper divides the figures of speech into schemes, tropes and additional imagery.

\section{Schemes}

Schemes are figures of speech that change the ordinary or expected pattern of words, often creating euphonic and mnemonic effects. Mnemonic devices that help advertising slogans to be remembered by their targeted audience include sound techniques such as alliteration, assonance, rhyme, anaphora, epiphora, meter and rhythm. These repetitions of formal patterns are called parallelisms.

\footnotetext{
1 Cited in William F. Arens, op. cit., p. 251.

2 Other Huckins Yachts' messages include IN A WORLD OBSESSED WITH STYLE, FEW ARE SO WELL-EQUIPPED TO OUTRUN THE PAPARAZZI and CONTRARY TO WHAT YOU'VE BEEN TOLD ALL YOUR LIFE. SHALLOWNESS IS A POSITIVE ATTRIBUTE, emphasising not just the style, but also the possibilities of these vessels due to their cutting-edge jet propulsion.

3 The famous De Beers company slogan A Diamond Is Forever / Diamonds Are Forever, one of the long-lasting slogans, was created in 1948 by Frances Gerety, a copywriter who worked for N. W. Ayer \& Sons, Inc.

4 David Ogilvy (1985). Ogilvy on Advertising. Vancouver: Vintage, p. 7, cited by Jana Lapšanská, in The language of advertising with the focus on the linguistic means and the analysis of advertising slogans, Comenius University in Bratislava, 2006.

${ }^{5}$ The latter classification was used by Milivoj Solar, Teorija književnosti, Školska knjiga, Zagreb, 1980, pp. 61-75. Jana Lapšanská, op. cit., analyses poetic elements of advertising slogans at four levels: phonology, morphology, syntax and semantics; T. Dubovičienè and P. Skorupa discuss a) Figurative language, b) Sound techniques and c) Other rhetorical devices in advertising slogans (The Analysis of some Stylistic Features of English Advertising Slogans, in: Man and the Word / Foreign Languages, Vol. 16, No. 3, pp. 61-75, Lithuanian University of Educational Sciences, 2014). There are over 150 figures of speech and many of them may fall in more than one category, e.g. antithesis, hyperbole, comparison and so on. Parallelisms like rhymes, anaphoras or alliterations are not just sound devices - they always affect the "meaning". Likewise, rhythm may result from using semantic, syntactic, lexical or phonological tools.
} 


\section{Parallelisms}

According to J. A. Cuddon, parallelisms are essential unifying elements in nearly all poetry and much prose. They may consist of "sounds, particular syllables and words, phrases, stanzas, metrical patterns, ideas, allusions and shapes". 1 Frequent sound techniques in advertising include assonance, the repetition of similar vowel sounds, usually close together, and alliteration, repetition of consonants, especially at the beginning of words or stressed syllables (in the following examples the assonance is underlined whereas the alliteration is marked in boldface type). These schemes achieve a particular effect of euphony. Alliteration is easily identified in Cruising with confidence (Elan Impression 354), Technologies to trust (Alfa Laval boat devices), Fashioning the future (CRN J'Ade 58M). Assonance is easily identified in Your imagination is the limit! (Vanga 44). Most often these schemes are combined to create a remarkable euphonic effect: Sea Symphony (Elan 400), The sunny side of life (Monachus power boats); Queen of the seas since 1968 (Ferretti Yachts); Motion and Mobility (ZF Transmissions); Set sail for success (Sealease service); $\boldsymbol{A}$ Riva is a Riva. Always. (Riva yachts - Ferretti Group). The latter is a good example of a mirror-like sound parallelism, so dear to French symbolist poet Stéphane Mallarmé, through the simple but strikingly efficient alteration of vowels and consonants [a-i-a-i-a-i-a // r-v-r-v]. Ferretti's corporate slogan Intelligenza nautica Italiana provides a remarkable euphonic effect through the sound parallelism including the assonance [i-e, i-e, i-a, i-a] and the alliteration [t-l-n, n-t, t-l-n]. Euphony is strong in Simply life saving (Lalizas life-saving equipment) [s-i-l-i-I-s-i]. It is striking in Sometimes solitude is the most exc/usive luxury [s-t-s, s-l-t-s, s-t-s-I, s-I-s] (Ferretti Yachts). In addition to euphonic effects, alliteration and assonance can help the slogans achieve "the strong beating rhythm needed to make it a repeatable sentence [...] easily remembered by the audience. " 2

chematic pattering in yachting slogans also include anaphoras and epiphoras. Anaphora is the repetition of the same word or set of words at the beginning of successive verses or sentences, emphasising an image or a concept, while epiphora is the repetition of the same word or words at the end of successive phrases, clauses or verses. Due to the format of the slogan, the space for introducing such schemes is limited. Nevertheless, anaphoras are not rare: One at a time. One of a kind. (Huckins Yachts), Great Sails, Great Sail Care! (North Sails), Feels like home. Feelin' alive (Bond Alena 48). Anaphora inevitably includes alliteration, in the latter case: [f-I-I // f-I-I]. Unlike advertisements of consumer goods, which abound with epiphoras, yachting slogans seldom use them. ${ }^{3}$ On the other hand, repetition of words may occur at other places: Explore your world without leaving your home (Bandido 75); A small family business for big family fun! (Splendor power catamarans). They often create an antithesis (your world - your home; small business - big fun), a figure of speech that will be dealt with later.

In advertising industry, rhyme is frequently used in jingles, slogans and headlines. English is particularly suitable for creating rhymes due to a large number of one-syllable words. While this poetic device is quite common in slogans advertising mass-consumption products (The best a man can get - Gillette; Do you ... Yahoo!? - Yahoo!), it is not very frequent in yachting ads, probably due to the fact that yachting slogans support custom-tailored, sophisticated and expensive products that do not abide "cheap" tools such as rhymes and jingles. Still, rhyme is not entirely avoided:

\footnotetext{
${ }^{1}$ Cuddon, J. A. (1999). The Penguin Dictionary of Literary Terms and Literary Theory. London: Penguin Books Ltd., p. 742.

2 Bui Thi and Bich Thuy, "An Investigation into the Style of the English Language Used in Advertising Slogans Issued by Some WorldFamous Airlines", in: ULIS, 2010.

${ }^{3}$ Here are some of the slogans supporting consumer goods, which contain epiphoras (marked in boldface type): If anyone can, Canon can (Canon), Buy it. Sell it. Love it (Ebay), It keeps going, and going, and going (Energizer Batteries), Heavy industries. Happy industries (Hyundai). Cited in T. Dubovičienè and P. Skorupa, op.cit., pp. 61-75.
} 


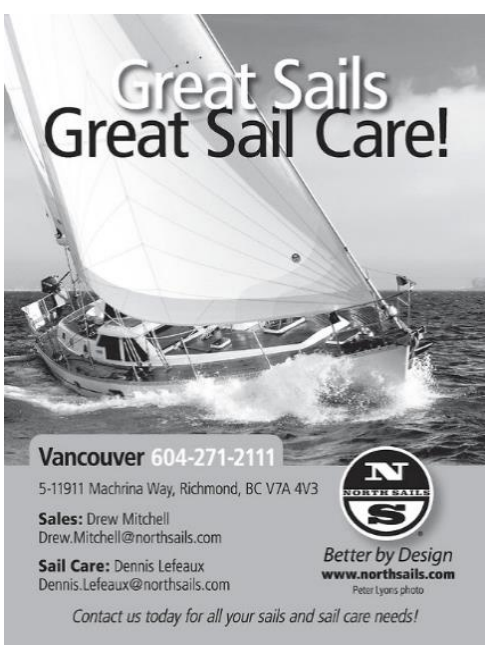

Source: http://www.northsails.com

Innovation, performance \& luxury. Be the part of Sunseeker family. (Sunseeker charter); Safe. Strong. Fast. Built to last.

(Tailored marine, Queensland).

Rhythm provides a powerful emotional and mnemonic effect that makes an advertisement or a slogan more memorable. In literature, rhythm can be achieved by an extensive use of euphonic tools such as assonance, alliteration and rhyme, as well as by the alteration of stressed and unstressed syllables. The repetition of similar or identical patterns of strong and weak stresses in lines of poetry is called metre. Yachting slogans almost always feature a regular metre (in the following examples the stressed syllables are marked in boldface type), such as an iamb, an unstressed syllable followed by a

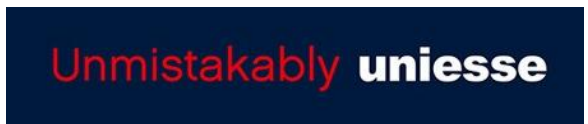

Source: http://www.uniesse.com stressed syllable (Become unique - Velvet 115); a trochee, a stressed syllable followed by an unstressed one (Powering business worldwide - Eaton powerware); a spondee, consisting of two stressed syllables (Your turn! - Lagoon 52); a molossus, having three stressed syllables (Speed. Style. Thrill. - Offshore, super classic 40); an anapaest, with two unstressed syllables followed by a stressed one (Feels like home. Feelin' alive - Bond Alena 48); an amphibrach, having a stressed syllable between two unstressed syllables (Imagine Perfection - Lazzara Yachts). Hanse yachts company's slogan Breaking rules. Setting trends. can be pronounced as two dactyls (with a stressed syllable followed by two unstressed syllables) or as two cretics (with an unstressed syllable between two stressed syllables).

In addition to euphonic and mnemonic quality, the rhythmic alternation of strong and weak syllables in yachting slogans has a synesthetic effect, suggesting the wave motion, i. e. the sailing feeling.

\section{Ellipsis and syncope}

In poetry, an ellipsis is the omission of words whose absence does not impede the reader's ability to understand the expression. Elliptical structure is a common phenomenon in advertising slogans. Phrases often lack essential elements such as nouns, verbs, conjunctions... In the tour-de-force slogans ISAKINDOFMAGIC and ISACHOICE, it is obvious that something is missing but it is not clear whether it is a noun, i. e. the boat Isa 120 , or the verb IS and the indefinite article $A$ - in case the capitals ISA are taken as the acronym of the Italian boatbuilder. According to Lapšanská, the reader of the advertisement "turns to the visual layout, which provides him/her many clues to correct interpretation, so the explicit 
structure of the sentence is not so important. "1 In Shuts down outboard thieves, it is not necessary to insist on the agent, as the name and image of the agent (Y-COP security system) appear in the photograph. Repetition of these elements would be needless. If the main verb is omitted, as in Unmistakably uniesse (Uniesse motoryachts), it is probably of no importance to define neither the tense nor the aspect of the verb. The sunny side of life is a cute, unpretentious phrase that sounds like a promise. It would be wrong and counter-productive to avoid the ellipsis and say "Monachus power boats take you to the sunny side of life / enable you to experience the sunny side of life."

Syncope is the omission of parts of a word or phrase. In everyday speech and in poetry, syncope refers to a contraction within a word through the loss of a vowel sound, as in the common British pronunciation of medicine as /'medsin/, but is sometimes extended to the loss of a consonant, as in boatswain > bosun. Syncope is sometimes indicated in writing by an apostrophe. While syncope in poetry results from poets' attempts to fit their words and lines of poetry to a specific rhythm and meter, syncopes and contractions in slogans rather try to create intimacy between the seller and the buyer: Feels like home. Feelin' alive - Bond Alena 48); SOMEDAY THEY'LL LOOK BACK JUST As FonDLY. (Vicem Yachts), an advertisement showing two kids at the yacht's bow, staring at the horizon.

\section{Comparison, simile and rhetorical questions}

Comparison is a rhetorical device in which advertisers compare or contrast two products, services, or ideas. One of the perceptible tactics is to use unqualified comparison, i. e. the use of words as "every", "always" or "none", where the second element of comparison is never stated: A Riva is a Riva. Always. (Riva yachts, Ferretti Group). Such slogans suggest that the advertised brand is perfect, or ultimate, or premium. Sometimes, in order to avoid overexploited lexis, slogans make use of a simile, "a figure of speech in which one thing is likened to another [...] to clarify and enhance an image. It is an explicit comparison (as opposed to the metaphor, where the comparison is implicit. ${ }^{2}$ It is recognizable by the use of the words 'like', 'than', 'as' or 'as if'. Simile usually underlines positive characteristics of the advertised product or service and strengthens emotional representation of its features: Feels like home. Feelin' alive. (Bond Alena 48); Different... Like you (Saltus brokerage \& charter); It's nothing like the real world (Yacht Week, Croatia).

Ordinary solutions such as more, better or best do not seem to be suitable enough for supporting sophisticated yachting brands. A rare exception is Simply the best (Dominator motor yachts). The message is very common, boring, and - worst of all - not original. Actually, it is one of the most overused phrases in the history of advertising. ${ }^{3}$

Rhetorical questions that assume one possible answer have been widely used in advertising business. If utilised correctly, they engage the target audience and help persuade them to come to a conclusion on their own, which has a greater effect then simply telling the audience to do something. The questions may be short (Got milk? - California Milk Processing Board) or rather long structures containing other rhetorical devices, e. g. hyperbole: (ISN'T SHE TRULY MORE OF EVERYTHING!? - Steeler Panorama FF53), but there is one thing they have in common - seeking a simple and quick answer, preferably "yes" or "no".

\section{Apposition}

Placing of two statements side by side, in which the second defines the first, is the simplest advertising phrase pattern. A brand name and the additional phrase in apposition create a metaphorical parallelism between a product and a feature: Vicem Yachts... Redefining Modern Luxury. (Vicem yachts); GREECE A MASTERPIECE YOU CAN AFFORD. This juxtaposition may be regarded as a sort of metaphor, or an elliptical comparison (without like or as). It can be even used as a means of contrast or antithesis.

Tropes Unlike schemes, which change the ordinary or expected pattern of words, tropes are figures of speech that change the general meaning of words.

\footnotetext{
1 Lapšanská, op. cit.

2 Cuddon, op. cit., p. 830.

${ }^{3}$ Brands and companies that used or have used it include American Legend, Amiga, MGM Auto Group, Sunshine Flights, and dozens of others (Timothy R. V. Foster, The Art and Science of the Advertising Slogan, ADSlogans Unlimited, 2001).
} 
Slogans supporting boating products and services feature a variety of words or phrases that are used in a way that is different from its usual meaning, in order to create a particular mental image or effect. Figurative language of yachting slogans often includes metaphor, metonymy, personification, hyperbole, antithesis and, less frequently, homonymy, polysemy, pun (word play), neologism and intertextuality.

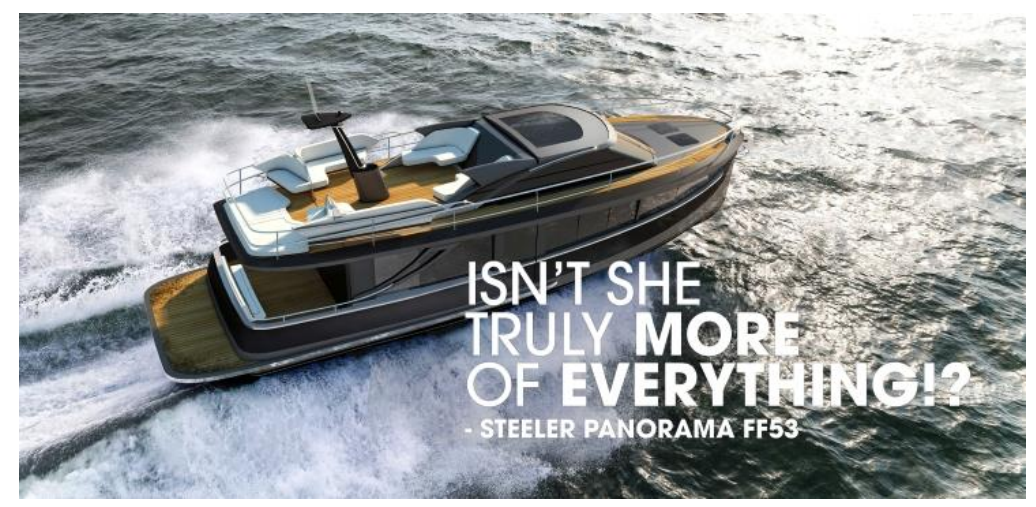

Source: http://www.steeleryachts.com

\section{Metaphor and metonymy}

Dubovičiene and Skorupa point out that metaphor "contributes to the aesthetics of the message and emphasizes the main idea, describing one object in terms of another, usually by means of implicit comparison", listing a number of famous slogans: Open Happiness (Coca Cola), It gives you wings (Red Bull), etc. ${ }^{1}$ Correspondingly, metaphor is an efficient tool in yachting ads. In The perfect mates for your next race. (Heuer yacht timers), the perfect mates are not companions or deck officers but watches and timers. A marine engine that provides propulsion and generates power can be regarded as The Heart of the Yacht (Volvo Penta D1-13), whereas a boat itself can be likened to Sea Symphony or Queen of the seas since 1968. According to Lapšanská, a single metaphor "may be worth of a hundred words of advertising text. It has an interesting value and stimulates the curiosity of the reader about the product". ${ }^{2}$

Metonymy uses a single characteristic of a person, product, system or phenomenon to identify the entire entity. The association is always logical. For example, the British monarchy is often referred to as the Crown. When a boater says "I like Yamaha", he or she uses metonymy to explain that he or she likes one part, not the whole entity, i. e. Yamaha marine engines, not Yamaha as a company. In Simplicity with style, metonymy is used to underline one of the recognisable features (simplicity) of a complex and therefore complicated product such as a cruising power yacht, namely Monachus lobster. There is also a noticeable effect of antithesis (simplicity / complexity).

\section{Antithesis and hyperbole}

Antithesis is a figure of speech which expresses two opposite ideas in order to emphasise the meaning and the contrast. It is based on antonyms, words of opposite meaning or opposite ideas: A small family business for big family fun! (Splendor power catamarans); Perfect Epoxy for an imperfect world (WEST System Epoxy); Where Land Ends, Life Begins (Sea Ray sports cruisers).

\footnotetext{
1 Dubovičienè and Skorupa, op. cit.

2 Lapšanská, op. cit.
} 
Hyperbole, a deliberate use of overstatement or exaggeration to achieve emphasis, is also frequent in yachting slogans: For Emperors and Princesses (Brioni 44); No storm can stop us (Aicon yachts); Making progress possible (Caterpillar marine engines); UNSURPASSED SERVICE (West Marine Megayacht Supply).

\section{Homonymy, polysemy and puns}

Homonyms are words that share the same pronunciation but have different meanings, whether spelled the same or not. ${ }^{1}$ These words are sometimes used by copywriters to create puns in advertising language: PERFORAMANCE ANYWEAR (Musto LPX clothing, wear and where are homophones). The US Superyacht Association's campaign Come Sea U. S. uses homonymy to promote the yachting industry in the United States. This kind of play works only in print and it cannot be recognised when spoken.

In homonymy there is no semantic connection between the two lexemes, only phonological one. On the other hand, a polyseme is a lexeme with two or more multiple, related meanings, so that the connection is not only phonological, but also semantic, as in The power to be independent (Mastervolt electric equipment) where power refers both to ability and electricity. These wordplays or puns have inevitable humorous effects and, as Dubovičienè and Skorupa assert, they can "work miracles" by capturing the attention and impressing people with smartness and novelty. ${ }^{2}$

Neologism, collocation and intertextuality

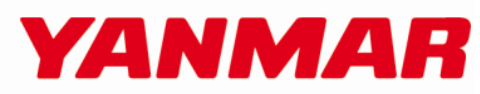

Solutioneering Together

Source: http://www.yanmar.com
Advertising texts take advantage of using made-up or adapted words and expressions in order to support the creative aspect of advertisement and its attraction. Neologisms are created by affixation, compounding, shortening and other ways. For example, affixation - the process of building new words by adding an established prefix or suffix to the existing base - is a very productive process of building new words in English: Solutioneering Together (Yanmar); IF IT SPEEDS, MOVES, SAILS, DOCKS, FLOATS, ROWS, PUTTERS, RACES, SKIMS OR ANCHORS OUT HERE, SUNBRELLA IS ON IT. (Sunbrella marine canvas).

A collocation is a sequence of words that occur more often than would be expected by chance: Breaking rules. Setting trends (Hanse); So worth it (Bayliner).

Intertextuality, the way one text echoes or refers to another text, a phenomenon sometimes difficult to recognize, e. g. Evolution of the species (Azimut 54), referring to Charles Darwin's theory of evolution; ISAKINDOFMAGIC (Isa 120), possibly referring to $A$ Kind of Magic, the twelfth album by English rock band Queen, released in 1986. In advertising, the intertextuality is best used when there is justifiable supposition that the original text is well-known among the targeted clientele.

\section{Personification and synaesthesia}

Other forms of figurative language in yachting slogans include personification, attribution of human qualities to inanimate objects (Yachts with Ambition - Steeler Yachts), and synaesthesia, blending of different sense modalities, e. g. warm colours, heavy silence, Blue Power (Victron Energy electric products). Synaesthesia became especially popular in the 19th century through the work of Charles Baudelaire, Arthur Rimbaud and the symbolist movement.

\footnotetext{
${ }^{1}$ In everyday contexts homonyms and homophones are used interchangeably. Strictly speaking, the word homophone is used to refer to words which sound alike, although they have a different spelling and meaning (e.g. mail / male; wear / ware), while homonyms refer to words which have the same spelling and pronunciation but have a different meaning (e.g. May / may). See Wikipedia at: https://en.wikipedia.org/wiki/Homonym).

2 Dubovičienè and Skorupa, op. cit. 
Additional imagery (lexical and syntactical elements) In addition to figures of speech, the poetics of slogans in yachting advertisements include specific motifs evoking the themes of being alive, capturing dreams, absence of limits, seeking adventure, independence, perfection, tranquillity, harmony, style, safety.

These are the values that are considered essential in boating and - as is often suggested - in living: Launch into living (Sea Ray), Dare to dream (Princess 58); Own the dream (Vicem yachts),

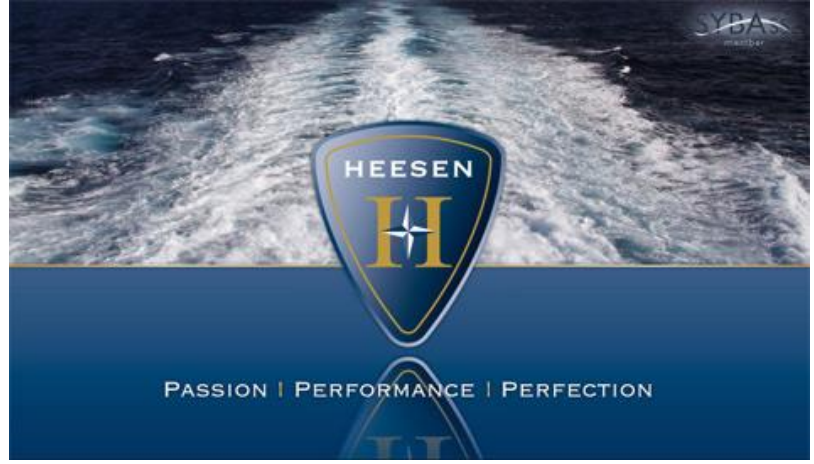

Source: http://www.heesenyachts.com

No limits (Mira, Alena \& Fashion Yachts), The value of the tranquillity (Lexsia yachts), Technologies to trust (Alfa Laval),

Performance at its best (Sunseeker Predator 80). Excessive use of certain motifs (performance, perfection, emotion, dream, style...) may reduce the strength of the desired effect.

It is not surprising that a copywriter unintentionally creates a slogan that already exists.

For instance, Passion, Performance, Perfection is used by Dutch yacht builder Heesen Yachts, while Passion, performance and perfection is used by Focus, German company that produces bicycles and cycling products. As it has been pointed out, one of the crucial tasks of a slogan is to help differentiate the brand. In this particular case, both slogans failed, not only because they are identical, but also because there are a number of slogans, in all sorts of trades, which use the same word corpus. The saturation of messages may lead to a glut of generic, hollow statements, i. e. cliché.

Sometimes proper nouns appear to support the message, referring to the producer (Mares bringing style and elegance to the world of catamarans - Mares) or one of the recognisable qualities of the brand (Built for the North Sea - Viknes motor boats). Azimut's daring slogan The best boat for British people... has been designed in Italy (Azimut Magellano 43) features an unexpected ending, an effect typical of a lyric poem. The effect is additionally reinforced by the alliteration of [b] in the first part, which suddenly disappears in the second part, releasing pure information (designed in Italy), relieved of any poetic tool, challenging British boatbuilding tradition and shocking potential consumers.

Being "poetic", yachting slogans seldom contain numerals. When they do, numerals usually evoke a tradition that guarantees the brand's quality: CREATEUR D'EMOTIONS DEPUIS 1973 (True North S. N. I. P Yachting), 125 years of heartfelt dedication (Dräger gas detecting equipment), Celebrating Adventure For 30 Years (Adriatic Croatia International Club).

Generally speaking, the choice of verbs is very careful in advertising. Yachting slogans largely follow the rules, avoiding any associations with buying or spending money. Instead, they make use of common alternatives such as enjoy or discover, but also introduce specific verbs that are related to the above mentioned values: dare, capture, launch, join, sail, keep, feel, imagine, dream...

The most frequent modal verb is "can": No storm can stop us (Aicon yachts), An idea can take you anywhere (Pershing power boats), Control Solutions You Can Trust (Dynagen Controller). These examples also contain possessive and personal pronouns that tend to shorten the distance between producers and consumers and are therefore used in advertising discourse more often than in other discourses. ${ }^{1}$

\footnotetext{
${ }^{1}$ Machynková, B. (2009). Translation in Advertising. Transfer vs Adaptation, Tomas Bata University in Zlin. 
The hull-side slogan of Beneteau's Oceanis 38 (YOUR BOAT. YOUR RULES. ) features possessive adjectives to highlight commitment to the customer, suggesting that the boat is built to a buyer's individual preferences.

The most powerful ones are pronouns you, your, we, us and our because they suggest personal relationship: Our technology, your emotion (Sacs S680); NO PASSION WITHOUT RISK... LEAVE THE RISK TO US. (Pantaenius Yacht Insurance). The syntax of the slogans promoting boats and boating equipment and services may include various sentence types.

Often, the advertising messages consist of elliptical noun phrases, as in Support without limits (BluePoint Yachting) or The Heart of the Yacht (Volvo Penta).

Adjectives are combined with nouns: Unbeatable for Quality and Performance (Gianneschi pumps and blowers) or used independently, usually in clusters, as in Reliable, Clean, Quiet - and Powerful (Cummins marine engines).

If verbs are used, the phrase may be exclamative: Your imagination is the limit! (Vanga 44), What a yacht (Bavaria); Way of life! (Suzuki outboard engines), but most frequently imperative: ENJOY THE EXPERIENCE (Dubai D3 Yacht rental), Join the movement (Garmin GPSMAP 720s); Keep Sailing (Hempel). Along with imperative, the prevailing verb forms include the Present Simple Tense, usually in the third person singular (feels / is / ends / begins...), and gerunds: Meeting regulations, protecting lives, lowering costs (McMurdo safety equipment). See also the above examples of slogans containing: feeling, solutioneering, fashioning, powering, breaking, setting, cruising... The described vocabulary, syntax, figurative language, rhetorical devices and metrical regularity contribute to the "mood" that pervades the advertising messages in yachting advertising, affecting their tone and poetics.

\section{Graphics}

The text of a slogan represents only one aspect of the advertising message. Other

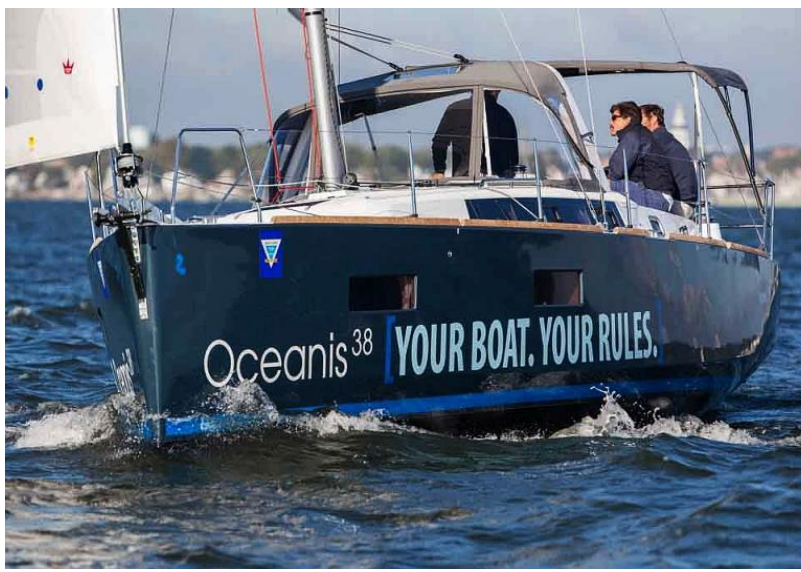

Source: http://www.beneteau.com

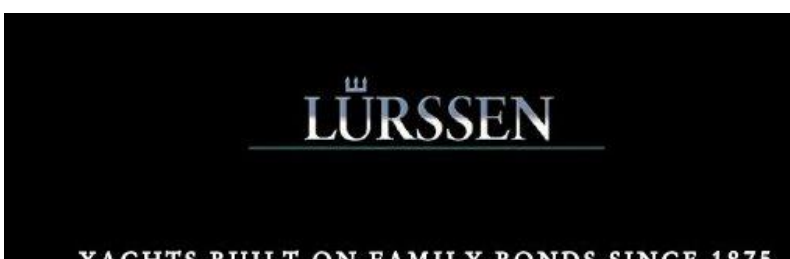

YACHTS BUILT ON FAMILY BONDS SINCE 1875

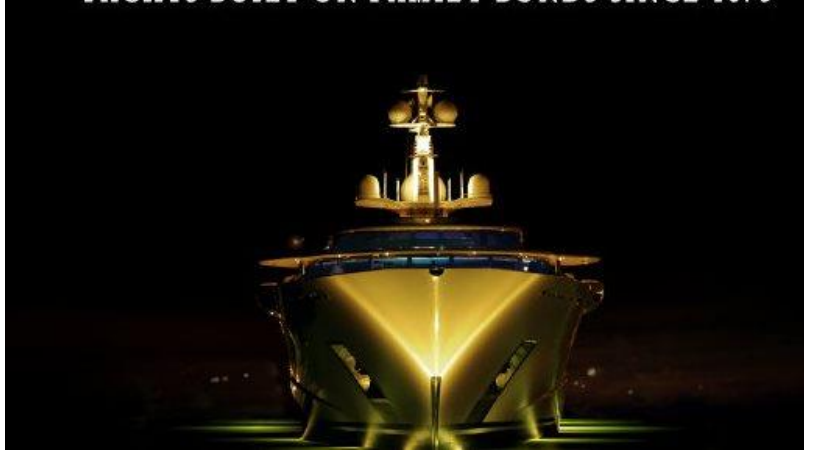

Source: www.luerssen-yachts.com elements include body text, technical description, photographs, audio and video material, etc. The 2008 Huckins Yachts' campaign produced advertisements exploring different aspects of their new brand. The yacht was taken to Bimini and put in various settings (open sea, coastal area, shallow inland waters). Photographs emphasize the key qualities of the yacht (craftsmanship, classic design, style, and possibilities resulting from fuel-saving jet-drive system) and so do the accompanying slogans: contrary to what you've been told all your life. Shallowness is a positive attribute; imagine owning a yacht that inspires you to stare at the scenery, not the fuel gauge. 
Although this paper focuses exclusively on the linguistic aspect of the yachting slogans, it would be just and perhaps interesting to highlight that some of the above examined poetic tools become recognisable only when media other than text are included in observation. In the already observed example of the Yamaha's slogan Shuts down outboard thieves, an ellipsis (omission of the agent) is made possible by juxtaposing the photograph of the agent (Y-COP security system). Advertisements of the prestigious German shipyard Lürssen $\mathrm{GmbH}$ feature the slogan Yachts built on family bonds since 1875. In addition to referring to tradition, the message unpretentiously implies that Lürssen is a family business. A consumer who is not familiar with Lürssen production may expect that a family-size boat would appear in the advertisement along with such a slogan, but here comes an inter-media antithesis: beneath the company's logo and slogan, there is an image of an impressive 91-metre Descout superyacht. Antithesis is noticeable in Huckins Yachts' slogans too: shallowness positive attribute; scenery - fuel gauge.

Advertisement designers pay particular attention to graphics - colour, type and size of the script. Typography and text layout can also be considered as poetic tools, especially having in mind radical techniques of Guillaume Apollinaire, a French poet and art critic of Polish descent. It is not possible here to engage in a detailed analysis of graphic features of yachting slogans, but it is only fair to draw attention to the most frequent technique - capitalisation. We can distinguish two types. Initial capitalization has an emphatic effect because the advertising message looks like a headline, like in Sea Ray's Where Land Ends, Life Begins. As a result, the meaning of each word is highlighted. Likewise, as in a number of the above examples, full capitalisation is used in advertising slogans for similar reason: in Heesen Yachts' PAssion, Performance, Perfection, words are written in small capital letters whereas the initials are normally capitalised, thus graphically reinforcing a strong alliteration of three P's and creating a beating effect - the rhythm. Different sizes of capitalisation were used in slogans of Huckins Yachts, Pantaenius Yacht Insurance, True North S. N. I. P Yachting, Sunbrella marine canvas etc., to emphasise the most important elements of the message. In an attempt to differentiate their brand, advertising text may be printed in a variety of fonts, sizes and colours.

\section{CONCLUSION}

Short advertising messages feature an amazing variety of poetic devices. If they were not referential, i. e. inherently referring to a specific purpose and meaning, advertising slogans, including the ones supporting products, services and events in recreational boating, could be considered as poetic forms determined by their own techniques, tone and content. The stylistic analysis, supported by qualitative, descriptive and comparative methods, has been used to identify and examine the poetic elements of slogans in yachting ads: schemes, tropes and additional imagery.

While rhymes - often associated with mass production - are rather rare, yachting slogans abound in other parallelisms such as alliteration, assonance, anaphoras and other devices that create euphony and rhythm. The latter is further reinforced by regular metres. Other schemes include ellipsis, simile and apposition, and - to a lesser extent - unqualified comparison and syncope. These tools provide strong euphonic and mnemonic effects that help slogans, and the brands they support, to be recognised and remembered.

Slogans that appear in boating magazines frequently use tropes, especially metaphor, metonymy, hyperbole, antithesis and unexpected ending, whereas homonymy, polysemy, pun, neologism, collocation, intertextuality, personification and synaesthesia are used less frequently. The complete absence of onomatopoeia, irony, paradox, oxymoron or tautology can be justified by the very trade, where too much wordplay around sophisticated products might be considered inappropriate.

On the other hand, the absence or low frequency of some figures of speech is potentially a great opportunity: from the business standpoint, it might be sound to use them more frequently, instead of insisting on the overexploited language resources that do not appeal to the targeted consumers any more.

The specific imagery in yachting slogans is usually associated with living, style, elegance, emotions, imagination, dreams, independence, exploration, solitude, harmony, perfection, reliability and safety. The analysis of the observed slogan corpus has revealed an excessive exploitation of certain motifs: living, dream, style, experience, passion, perfection... Such slogans become trite, vacuous phrases to an average consumer and fail to carry out their principal task - to differentiate the brand (e. g. Passion, Performance, Perfection). 
Due attention has been paid to the graphic aspects of some advertisements. The visual layout provides clues to correct interpretation, so that the explicit structure of the sentence is not so important. This allows the use of ellipsis, hyperbole, antithesis and other figures of speech, while the initial or full capitalisation of letters graphically reinforces the message.

Yachting slogans rarely use questions, rhetorical questions that assume one possible answer, presuppositions, or comparisons with other brands. Elliptical structures and noun phrases, with or without adjectives, are dominant. When verbs are used, the most frequent forms include Present Simple Tense, imperative and gerund. As is the case in other trades, any association with buying or spending money is carefully avoided - instead, verbs like get, enjoy or discover are used, in addition to the ones specifically related to yachting: dare, capture, launch, sail, imagine... Pronouns like you, we, us, our, your... are essential in suggesting personal relationship between producers and consumers.

It commonly occurs that a slogan contains a set of various figures of speech: Feels like home. Feelin' alive (anaphora, alliteration, anapaest, syncope, simile) Queen of the seas since 1968 (alliteration, assonance, metaphor), Sea Symphony (capitalisation, alliteration, assonance / rhyme, metaphor), Making progress possible (alliteration, iambic metre, hyperbole), or powerful sound parallelisms, as in Sometimes solitude is the most exclusive luxury [s-t-s, s-l-t-s, s-t-s-l, s-l-s]. This often results in dense messages, loaded with obvious and less obvious nuances and connotations, which may easily be mistaken for the lines of "real" poetry. Whether this suffices to consider them as a poetic form or genre with a distinct "personality" remains an issue for further research and discussion.

\section{REFERENCES}

\section{Primary sources}

More magazine, Fabra press d. o. o., Croatia, January-December 2010.

Nautica (Croatian edition), Profectus media d. o. o., Split, Croatia, January-December 2009.

Val navtika magazine, Val navtika d. o. o., Ljubljana, Slovenia, January-December 2013. (www. val-navtika. net)

Yachts Croatia, D. Š. Savjetovanje d. o. o., Split, Croatia, No. 25-30 (January-December 2013). (http://issuu. com/yachtscroatia)

Google, 2016-01-14 (search words: "yachting ads")

\section{Secondary sources}

Arens, W. F. (1994). Contemporary advertising, $5^{\text {th }}$ edition. Irwin, USA.

Conley, S. J. (2010). Sloganology: The Anatomy Of Slogans. eBook, 2010. Available at: www. thesloganshop. com (201601-23)

Cuddon, J. A. (1999). The Penguin Dictionary of Literary Terms and Literary Theory. London: Penguin Books Ltd.

Dubovičienè, T., \& Skorupa, P. (2014). The Analysis of some Stylistic Features of English Advertising Slogans. Man and the Word / Foreign Languages, Vol. 16, No. 3, Lithuanian University of Educational Sciences, DOI: http://10. 15823/zz. 2014. 013, pp. 61-75.

Foster, T. R. V. (2001). The Art \& Science of the Advertising Slogan, ADSlogans Unlimited. Available at: www. adslogans. co. uk (2016-01-23)

Ke, Q., \& Wang, W. (2013). The Adjective Frequency in Advertising English Slogans. Theory and Practice in Language Studies, Vol. 3, No. 2, pp. 275-284, Academy Publication, February 2013, doi:10. 4304/tpls. 3. 2. 275-284 ISSN 1799-2591; available at: http://ojs. academypublisher. com/index. php/tpls/article/view/tpls0302275284/6286 (2016-01-23) 
Leech, G. N. (1966/1972). English in Advertising: a linguistic study of advertising in Great Britain. Longman, London.

Lapšanská, J. (2006). The language of advertising with the focus on the linguistic means and the analysis of advertising slogans, Comenius University in Bratislava.

Machynková, B. (2009). Translation in Advertising. Transfer vs Adaptation, Tomas Bata University in Zlin.

O'Guinn, T. C., Allen, C. T., \& Semenik, R. J. (2012). Advertising and integrated brand promotion, 6th ed., Mason, OH: South-Western, Cengage Learning.

Rein, D. P. (1982). The Language of Advertising and Merchandising in English. Regent, New York.

Solar, M. (1980). Teorija književnosti, Školska knjiga, Zagreb, Croatia.

Solomon, E. (Ediwriter Professional Copywriting Co. ), New York City, USA. Available at http://www. ediwriter. com (201601-23)

Thi, Bui \& Thuy, Bich (2010). An Investigation into the Style of the English Language Used in Advertising Slogans Issued by Some World-Famous Airlines. ULIS.

https://en. wikipedia. org/wiki/Slogan (2016-01-23) 